\title{
Artículo Original / Original Article Antioxidant and antibacterial activity of Myrcianthes pungens leaf essential oil
}

[Actividad antioxidante y antibacteriana del aceite esencial de hoja de Myrcianthes pungens]

\author{
Renan Almeida de Jesus ${ }^{1}$, Herika Line Marko de Oliveira ${ }^{1}$, Wanessa de Campos Bortolucci' ${ }^{1}$, \\ Caio Franco de Araújo Almeida Campo², Maria Graciela Iecher Faria ${ }^{1}$, José Eduardo Gonçalves², \\ Nelson Barros Colauto ${ }^{1}$, Zilda Cristiani Gazim ${ }^{1} \&$ Giani Andrea Linde ${ }^{1}$
}

\begin{abstract}
${ }^{1}$ Programa de Pós-Graduação em Biotecnologia Aplicada à Agricultura. Universidade Paranaense, Umuarama, PR, Brasil
${ }^{2}$ Mestrado em Tecnologia Limpas e Instituto Cesumar de Ciência, Tecnologia e Inovação, UniCesumar, Maringá, PR, Brasil
\end{abstract}

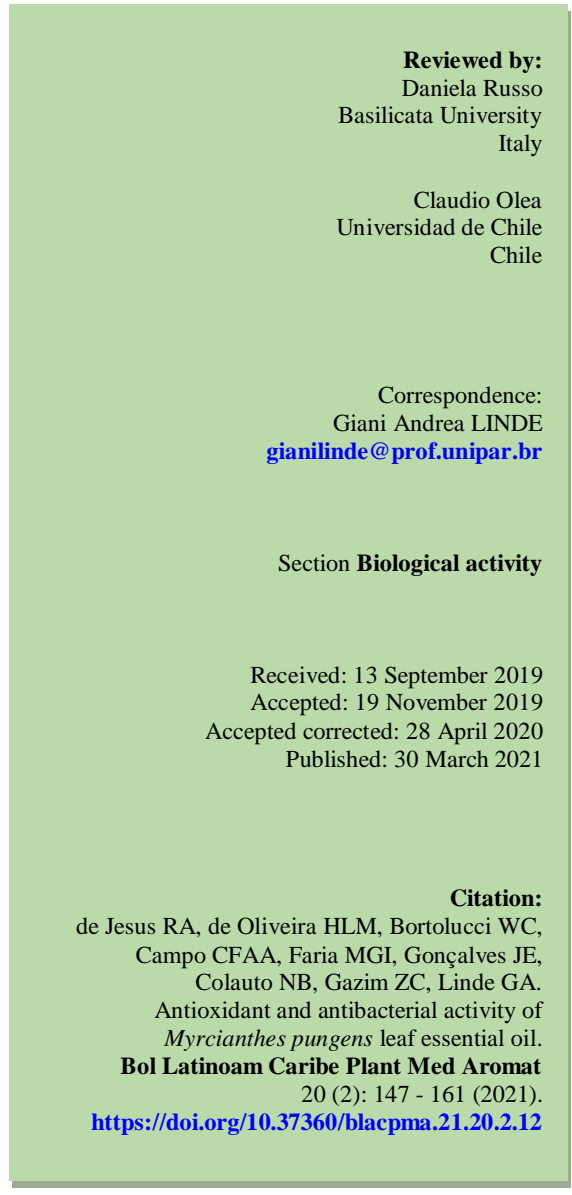

Abstract: Myrcianthes pungens (Myrtaceae) is a native tree to Brazil known as guabijú. In our study, we described the chemical composition of the essential oil from $M$. pungens dried leaves, the antioxidant activity by different methods and antibacterial activity against Staphylococcus aureus, Bacillus cereus and Pseudomonas aeruginosa. The chemical identification was done by gas chromatograph coupled to mass spectrometer and antibacterial activity was evaluated by broth microdilution method. The leaf essential oil presented hydrocarbon sesquiterpenes $(42.6 \%)$ as its main chemical class whose major compounds were $\beta$-caryophyllene (11.7\%) and 1,8-cineole (10.1\%). The best antioxidant protection was from 57.5 to $63.3 \%$ of $\beta$-carotene. The highest antibacterial activity was against $S$. aureus (MIC of 78.12 $\mu \mathrm{g} / \mathrm{mL}$ ). This value was 2.56 -fold lower than the positive streptomycin control. M. pungens is a promising source of natural molecules with potential study for the development of pharmacological, cosmetic and food products.

Keywords: $\beta$-caryophyllene; 1,8 -cineole; $\beta$-carotene/linoleic acid co-oxidation; Sesquiterpenes; Guabijú; Myrtaceae.

Resumen: Myrcianthes pungens (Myrtaceae) es un árbol nativo de Brasil conocido como guabijú. En nuestro estudio, describimos la composición química del aceite esencial de las hojas secas de M. pungens, la actividad antioxidante por diferentes métodos y la actividad antibacteriana contra Staphylococcus aureus, Bacillus cereus y Pseudomonas aeruginosa. La identificación química se realizó mediante un cromatógrafo de gases acoplado a un espectrómetro de masas y la actividad antibacteriana se evaluó mediante un método de microdilución en caldo. El aceite esencial de la hoja presentó sesquiterpenos de hidrocarburos $(42,6 \%)$ como su principal clase química cuyos compuestos principales fueron $\beta$ cariofileno $(11,7 \%)$ y 1,8 -cineol $(10,1 \%)$. La mayor protección antioxidante fue de 57.5 a $63.3 \%$ de $\beta$ caroteno. La mayor actividad antibacteriana fue contra $S$. aureus (MIC de $78.12 \mu \mathrm{g} / \mathrm{mL}$ ). Este valor fue 2,56 veces menor que el control positivo de estreptomicina. $M$. pungens es una fuente prometedora de moléculas naturales con potencial estudio para el desarrollo de productos farmacológicos, cosméticos y alimenticios.

Palabras clave: $\beta$-Cariofileno; 1,8-Cineol; Co-oxidación de $\beta$-Caroteno/Ácido linoleico; Sesquiterpenos; Guabijú; Myrtaceae. 


\section{INTRODUCTION}

The most utilized synthetic antioxidants such as BHA (butyl hydroxyl anisole), BHT (butylated hydroxyl toluene), and TBHQ (tertiary butyl hydroquinone) have molecules that are capable of stabilizing free radicals and preventing the initiation of oxidation chains (Yehye et al., 2015). However, they can also exhibit a pro-oxidant behavior at high concentrations, causing molecule reduction and inducing the oxidative process (Marin et al., 2008; Škrovánková et al., 2012). These compounds have also been associated to adverse effects such as carcinogenesis and damages to the liver and lungs (Suh et al., 2005). Food and cosmetics consumers have valued products without the addition of synthetic preservatives. Food spoilage is a serious widely neglected problem, mainly in grain due to poor harvesting practices, inappropriate drying, handling, packaging, storage, and transport conditions. The utilization of synthetic antibiotics or chemicals has increased microorganism resistance, mostly against antibiotics and the search for new antimicrobials is an alternative to reduce synthetic chemicals uses to extend shelf life and prevent foodborne pathogens (Anyanwu \& Okoye, 2017). Plant essential oils are a source of new molecules and from 1981 to 2010 approximately one third of the drugs approved by FDA (Food and Drug Administration from United States of America) were from plant molecules (Newman \& Cragg, 2012).

Myrcianthes pungens (Berg) C. D. Legrand and its synonyms Acreugenia pungens (Berg) Kausel, Eugenia pungens Berg, Eugenia ybaviyu Parodi, and Luma pungens (Berg) Herter (Hassler, 2019), popularly known as guabijú and guabirá (in Portuguese) is geographically distributed in Brazil, Paraguay, Bolivia, Uruguay, and Argentina. It is an evergreen tree with up to $25 \mathrm{~m}$ height and round canopy, light reddish and smooth trunk. Its bright dark green petiolate leaves have pointed end and rounder base, measuring from 3.5 to $7.6 \mathrm{~cm}$ length and from 1.4 to $3.4 \mathrm{~cm}$ width. Its fruits are sweet, round and smooth with $1-\mathrm{cm}$ diameter average, and they have dark purplish color when ripe (Marin et al., 2008). M. pungens leaves have essential oil (Zygadlo et al., 1997; Apel et al., 2006), but they have been little studied, differently from fruits which are edible and present antioxidant activity (Andrade et al., 2011), reduce hypercholesterolemia induced by cisplatin in rats (Nora et al., 2014), and antichemotactic activity (Andrade et al., 2011).

Moreover, the utilization of leaves is more sustainable and economically viable than fruits due to the possibility of collecting them throughout the year instead of a single yearly fruit harvest. Thus, this study aimed to characterize the chemical composition of the essential oil from $M$. pungens leaves and evaluate its antioxidant and antibacterial activity for potential applications in the food, pharmaceutical and cosmetic industries.

\section{MATERIAL AND METHODS Biological material}

Myrcianthes pungens can be found at latitude $24^{\circ} 59^{\prime} 17.2^{\prime \prime S}$ and longitude $53^{\circ} 28^{\prime} 00.4^{\prime \prime} \mathrm{W}$; its leaves were collected in April 2017, from 7h to 9h o'clock in the morning, in the vegetative phase, and dried in the shade at ambient temperature $\left(\sim 30^{\circ} \mathrm{C}\right)$ for 10 days. The plant was identified and deposited in the herbarium of Maringá State University under the registration HUEM-32695, and registered in the National System for the Management of Genetic Heritage and Associated Traditional Knowledge (SisGen, acronym in Portuguese) under the registration AA3F7DB.

\section{Essential oil extraction}

The essential oil was extracted from leaves that were dried and ground in a mixer with ultrapure water and submitted to hydrodistillation in a modified Clevenger for $2 \mathrm{~h}$ (Apel et al., 2006). The essential oil was dehydrated by filtration in anhydrous sodium sulfate, stored in an amber flask and kept under refrigeration.

The leaf essential oil yield was calculated by the essential oil mass divided by the dried leaf mass, multiplied by 100 and expressed in percentage. The essential oil density was determined at $20^{\circ} \mathrm{C}$ in 5.0 $\mu \mathrm{L}$ graduated capillaries (mass/volume). The refraction index was determined by refractometer (Abbe RL3 model) calibrated with ultrapure water (refraction index of 1.3330 ) at $20^{\circ} \mathrm{C}$ (Farmacopeia Brasileira, 2010).

\section{Identification of chemical compounds}

Sample of $1 \mu \mathrm{L}$ dichloromethane (HPLC degree) with essential oil $(20 \mathrm{mg} / \mathrm{mL})$ was used for each analysis. The chemical identification carried out by gas chromatograph (Agilent 7890B) coupled to a mass spectrometer (GC-MS) (Agilent 5977A MSD) and a HP5-MS UI Agilent fused silica capillary column $(30 \times 250 \times 0.25 \mu \mathrm{m}$; Agilent Technologies $)$, with initial oven temperature from $80^{\circ} \mathrm{C}(1 \mathrm{~min})$, followed by increased to $185^{\circ} \mathrm{C}$ at $2^{\circ} \mathrm{C} / \mathrm{min}$ and maintained for $1 \mathrm{~min}$, followed by an increase to $275^{\circ} \mathrm{C}$ at $9^{\circ} \mathrm{C} / \mathrm{min}$ and maintained for $2 \mathrm{~min}$ and finally increased to $300^{\circ} \mathrm{C}$ at $25^{\circ} \mathrm{C} / \mathrm{min}$ and 
maintained for $1 \mathrm{~min}$. Helium was utilized as the carrier gas at the linear speed of $1 \mathrm{~mL} / \mathrm{min}$ up to $300^{\circ} \mathrm{C}$, and pressure release of $56 \mathrm{kPa}$. The injector temperature was $280^{\circ} \mathrm{C}$; the injection volume was 1 $\mu \mathrm{L}$; the injection occurred in split mode (2:1). The temperatures of the transfer line, ion source and quadrupole were $280^{\circ} \mathrm{C}, 230^{\circ} \mathrm{C}$ and $150^{\circ} \mathrm{C}$. The $\mathrm{EM}$ detection system was utilized in "scan" mode, at the mass/charge rate/load $(\mathrm{m} / \mathrm{z})$ of 40-600, with "solvent delay" of $3 \mathrm{~min}$. The compounds were identified by comparing the mass spectra found in NIST 11.0 libraries and by comparing the retention index (RI) obtained by a homologous series of $n$-alkane standard $\left(\mathrm{C}_{7}-\mathrm{C}_{28}\right)$ (Adams, 2012).

\section{Antioxidant activity}

\section{2,2-diphenyl-1-picrylhydrazyl (DPPH*) method}

The essential oil sequestration capability of free radicals by 2,2-diphenyl-1-picrylhydrazyl (DPPH') was made according Rufino et al. (2007). The essential oil was prepared in methanol at 1.00, 0.75, 0.50 , and $0.25 \mathrm{mg} / \mathrm{mL}$ and $0.1 \mathrm{~mL}$ this mixture was added to $3.9 \mathrm{~mL} \mathrm{DPPH}^{*}$ methanolic solution $(60$ $\mu \mathrm{M})$. The negative control had $0.1 \mathrm{~mL}$ methanol in $\mathrm{DPPH}^{*}$ solution $(60 \mu \mathrm{M})$. The mixture was kept in the dark at room temperature for $30 \mathrm{~min}$ and the absorbance reduction was measured in $515 \mathrm{~nm}$ in a UV/VIS spectrophotometer. The total antioxidant capacity was calculated utilizing a standard quercetin solution $(60 \mu \mathrm{M})$ as a $100 \%$ reference. From the correlation between absorbance and concentration of the antioxidant sample, the inhibitory concentration to reduce $50 \%$ of the free radicals $\left(\mathrm{IC}_{50}\right)$ was determined.

\section{$\beta$-carotene/linoleic acid (BCLA) method}

The antioxidant activity of the essential oil was evaluated using the method based on $\beta$ carotene/linoleic acid (BCLA) co-oxidation system. A $1.0-\mathrm{mL}$ solution (20 mg BCLA in $1 \mathrm{~mL}$ chloroform) was mixed to $40 \mu \mathrm{L}$ linoleic acid and $530 \mu \mathrm{L}$ polisorbate-40 emulsifier. Chloroform was removed in a rotary evaporator at $50^{\circ} \mathrm{C}$, and $450 \mathrm{~mL}$ of ultrapurified water (previously saturated with oxygen for $30 \mathrm{~min}$ ) was added under vigorous agitation until reaching absorbance of 0.7 at $470 \mathrm{~nm}$. Aliquots $(280 \mu \mathrm{L})$ of this emulsion were transferred to microplates with 96 wells. In each well $20 \mu \mathrm{L}$ ethanolic solution with essential oil at 1.00, 0.75, 0.50 , or $0.25 \mathrm{mg} / \mathrm{mL}$ was poured. The reaction was kept at $40^{\circ} \mathrm{C}$ for $120 \mathrm{~min}$ and the absorbance was measured at $470 \mathrm{~nm}$ in spectrophotometer (Spectra Max Plus ${ }^{384}$ Microplate Reader) every 5 min of zero time until $120 \mathrm{~min}$. Trolox (6-hydroxy-2,5,7,8tetramethylchroman-2-carboxylic acid) was utilized as a reference at $100 \mu \mathrm{g} / \mathrm{mL}$. The results were expressed in absorbance reduction along the reaction time. The $\beta$-carotene bleaching rate was calculated according to Equation No. 1.

$$
\mathbf{R}=\ln (\mathbf{a} / \mathbf{b}) / \mathbf{t}
$$

where $\mathrm{R}=$ bleaching rate of $\beta$-carotene in the mixture; $\ln =$ natural $\log ; \mathrm{a}=$ absorbance in zero time; $\mathrm{b}=$ absorbance in $\mathrm{t}$ time $(\mathrm{t}=0,5,10, \ldots 120$ $\min )$.

The antioxidant activity was calculated according to the percentage of inhibition in relation to the control, using Equation No. 2.

$$
\mathrm{AA}=\left[\left(\mathbf{R}_{\text {control }}-\mathbf{R}_{\text {sample }}\right) / \mathbf{R}_{\text {control }}\right] \times \mathbf{1 0 0}
$$

where $\mathrm{AA}=$ Antioxidant activity; $\mathrm{R}_{\text {control }}$ and $\mathrm{R}_{\text {sample }}$ were the bleaching rates of $\beta$-carotene in the mixture without the antioxidant $\left(\mathrm{R}_{\text {control }}\right)$ and with essential oil

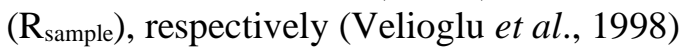

\section{Ferric reducing antioxidant power (FRAP)}

For the ferric reducing antioxidant power (FRAP), 25 $\mathrm{mL}$ acetate buffer $(0.3 \mathrm{M}), 2.5 \mathrm{~mL}$ TPTZ $(2,4,6$-Tris (2-piridil)-triazine) aqueous solution $(10 \mathrm{mM})$ and $2.5 \mathrm{~mL}$ ferrous chloride aqueous solution $(20 \mathrm{mM})$ were mixed according to Rufino et al. (2006). Essential oil $(90 \mu \mathrm{L})$, previously prepared in methanol at $1.00,0.75,0.50$, or $0.25 \mathrm{mg} / \mathrm{mL}$, was mixed to $2.7 \mathrm{~mL}$ FRAP reagent for the antioxidant activity reaction. The mixture was vigorously homogenized and kept at $37^{\circ} \mathrm{C}$ for $30 \mathrm{~min}$. The absorbance variance was read at $595 \mathrm{~nm}$. A standard curve of ferrous sulfate $(0-2000 \mu \mathrm{M})$ was used to calculate the antioxidant activity. The antioxidant activity was expressed in $\mu \mathrm{M}$ of ferrous sulfate per mg of sample.

\section{Antibacterial activity}

The antibacterial activity of essential oil was evaluated by broth microdilution method (adapted CLSI method) (CLSI, 2006) with three bacteria: Staphylococcus aureus subsp. aureus Rosenbach (ATCC $^{\circledR} 14458^{\mathrm{TM}}$ ), Bacillus cereus Frankland and Frankland (ATCC ${ }^{\circledR} 14579^{\mathrm{TM}}$ ), and Pseudomonas aeruginosa (Schroeter) Migula (ATCC ${ }^{\circledR} 27853^{\mathrm{TM}}$ ). Each bacterium was cultivated in nutrient broth $\left(\mathrm{DIFCOR}^{\circledR}\right.$ ) at $37^{\circ} \mathrm{C}$ and kept in sloped nutrient agar at room temperature. 


\section{Standardization of bacterial suspension}

From a $24 \mathrm{~h}$ bacterial culture, a new cultivation in Mueller-Hinton (DIFCOR ${ }^{\circledR}$ ) broth for $8-10 \mathrm{~h}$ was done. After that, in a tube containing sterile saline solution $(0.9 \% \mathrm{NaCl})$, the bacterial culture was added until obtaining turbidity identical to the one compared to the tube with $0.5 \mathrm{McF}$ arland standard $\left(\mathrm{BaSO}_{4}\right.$ suspension which corresponds to $1.010^{8}$ $\mathrm{CFU} / \mathrm{mL}$ ). A dilution of 1:10 in Mueller-Hinton broth was done to obtain $10^{7} \mathrm{CFU} / \mathrm{mL}$ bacterial suspension, which was utilized as inoculum in the assay to determine the minimum inhibitory concentration (MIC) (CLSI, 2006).

\section{Broth dilution method}

The essential oil was diluted in ultrapure water at 40 $\mathrm{mg} / \mathrm{mL}$ utilizing $2 \%$ polisorbate- 80 as solubilizing agent. In a microplate with 96 wells, $90 \mu \mathrm{L}$ MuellerHinton broth was added to each well except for the ones in column 1 , and $100 \mu \mathrm{L}$ diluted essential oil were added to the wells of columns 1 and 2. Serial dilutions were done from column 2 and, then, $10 \mu \mathrm{L}$ inoculum were added to each well, totaling a final volume of $100 \mu \mathrm{L}$. The microplates were incubated at $37^{\circ} \mathrm{C}$ for $24 \mathrm{~h}$ and streptomycin $(200.0 \mathrm{mg} / \mathrm{mL})$ was used as positive control. After that, $10 \mu \mathrm{L} \mathrm{2,3,5-}$ triphenyltetrazolium chloride was added to each well and in $10 \mathrm{~min}$ at $37^{\circ} \mathrm{C}$ the microbial growth inhibition was observed to determine MIC. The absence of pink color indicated microbial growth inhibition (CLSI, 2006).

\section{Statistical analysis}

The results were submitted to analysis of variance (Anova) and the differences between the arithmetical means and standard deviation were determined by Tukey test $(p \leq 0.05)$. All tests were done in triplicates.

\section{RESULTS}

The essential oil yield of $M$. pungens dried leaves was $0.19 \pm 0.04 \%$ with density of $0.98 \mathrm{~g} / \mathrm{mL}$ and refraction index of 1.4980 . The essential oil presented sesquiterpenes as the main chemical class: $42.6 \%$ hydrocarbon sesquiterpenes and $30.7 \%$ oxygenated sesquiterpenes (Table No. 1). The major compounds (greater or equal to $6 \%$ ) were $\beta$-caryophyllene (11.7\%), 1,8-cineole (10.1\%), bicyclogermacrene $(7.9 \%)$, spathulenol $(7.8 \%)$, and 5-epineointermedeol (6.0\%). The essential oil chromatogram is represented in Figure No. 1 and the mass spectra of the major compounds can be seen in Figures No. 2, No. 3, No. 4, No. 5 and No. 6.

Table No. 1

Chemical composition of essential oil from Myrcianthes pungens leaves obtained by gas chromatograph coupled to mass spectrometer

\begin{tabular}{|c|c|c|c|c|}
\hline Peak & ${ }^{\text {aCCompound }}$ & Relative area $(\%)$ & ${ }^{\mathrm{b}} \mathbf{R I}$ & Identification methods \\
\hline 1 & $\alpha$-thujene & 0.12 & 929 & $a, b, c$ \\
\hline 2 & $\alpha$-pinene & 0.46 & 936 & $a, b, c$ \\
\hline 3 & Canphene & $\mathrm{t}$ & 952 & $a, b, c$ \\
\hline 4 & n.i. & 0.13 & 965 & $\mathrm{a}, \mathrm{b}, \mathrm{c}$ \\
\hline 5 & Sabinene & 0.11 & 976 & $a, b, c$ \\
\hline 6 & $\beta$-pinene & 0.48 & 979 & $a, b, c$ \\
\hline 9 & $\delta$-3-carene & 0.16 & 1012 & $a, b, c$ \\
\hline 10 & $\alpha$-terpinene & 0.38 & 1018 & $\mathrm{a}, \mathrm{b}, \mathrm{c}$ \\
\hline 11 & $p$-cymene & 1.39 & 1027 & $a, b, c$ \\
\hline 12 & Limonene & 3.52 & 1031 & $a, b, c$ \\
\hline 13 & 1,8-cineole & 10.10 & 1035 & $a, b, c$ \\
\hline 17 & Terpinolene & 0.60 & 1089 & $\mathrm{a}, \mathrm{b}, \mathrm{c}$ \\
\hline 18 & Linalool & $\mathrm{t}$ & 1100 & $a, b, c$ \\
\hline 19 & $p$-menth-2-en-1-ol & $\mathrm{t}$ & 1123 & $a, b, c$ \\
\hline 20 & Terpinen-4-ol & 1.58 & 1178 & $a, b, c$ \\
\hline 21 & $\alpha$-terpineol & 1.55 & 1191 & $a, b, c$ \\
\hline 22 & $\alpha$-cubebene & 2.82 & 1351 & $a, b, c$ \\
\hline
\end{tabular}




\begin{tabular}{|c|c|c|c|c|}
\hline 23 & $\alpha$-copaene & 0.22 & 1375 & $a, b, c$ \\
\hline 24 & $\beta$-elemene & 3.01 & 1391 & $a, b, c$ \\
\hline 25 & $\alpha$-gurjunene & 0.33 & 1407 & $a, b, c$ \\
\hline 26 & $\beta$-caryophyllene & 11.70 & 1419 & $a, b, c$ \\
\hline 27 & $\gamma$-elemene & 0.14 & 1433 & $a, b, c$ \\
\hline 28 & Aromadendrene & 0.58 & 1437 & $a, b, c$ \\
\hline 29 & $\alpha$-humulene & 1.69 & 1449 & $a, b, c$ \\
\hline 32 & Germacrene D & 0.36 & 1467 & $a, b, c$ \\
\hline 33 & $\beta$-selinene & 3.44 & 1471 & $a, b, c$ \\
\hline 34 & $\gamma$-selinene & 0.86 & 1476 & $a, b, c$ \\
\hline 35 & Valencene & $\mathrm{t}$ & 1481 & $a, b, c$ \\
\hline 40 & $\gamma$-cadinene & 0.17 & 1512 & $a, b, c$ \\
\hline 41 & $\delta$-cadinene & 2.99 & 1522 & $a, b, c$ \\
\hline 42 & cadina-1-4-diene & 0.53 & 1531 & $a, b, c$ \\
\hline 43 & Germacrene B & 2.21 & 1555 & $a, b, c$ \\
\hline 44 & Aristolene & 0.60 & 1565 & $a, b, c$ \\
\hline 45 & Spathulenol & 7.81 & 1577 & $a, b, c$ \\
\hline 46 & Caryophyllene oxide & 5.17 & 1582 & $a, b, c$ \\
\hline 47 & Globulol & 1.31 & 1589 & $a, b, c$ \\
\hline 48 & Viridiflorol & 0.95 & 1591 & $\mathrm{a}, \mathrm{b}, \mathrm{c}$ \\
\hline 49 & Guaiol & 0.62 & 1599 & $a, b, c$ \\
\hline 57 & $\alpha$-cadinol & 0.45 & 1646 & $a, b, c$ \\
\hline 58 & 5-epi-neointermedeol & 6.03 & 1654 & $a, b, c$ \\
\hline 59 & Valerenol & 0.33 & 1668 & $a, b, c$ \\
\hline 60 & Caryophylla-3,8(13)-dien-5- $\beta$-ol & 0.48 & 1670 & $\mathrm{a}, \mathrm{b}, \mathrm{c}$ \\
\hline 61 & Aristol-9-en-3-ol & 0.27 & 1696 & $a, b, c$ \\
\hline 62 & Calarene epoxide & 0.28 & 1714 & $a, b, c$ \\
\hline \multirow[t]{7}{*}{63} & $\gamma$-costol & 0.88 & 1718 & $a, b, c$ \\
\hline & Total identified & 98.81 & & \\
\hline & Hydrocarbon monoterpenes & 13.11 & & \\
\hline & Oxygenated monoterpenes & 13.23 & & \\
\hline & Hydrocarbon sesquiterpenes & 42.60 & & \\
\hline & Oxygenated sesquiterpenes & 29.87 & & \\
\hline & Non-identified & 0.99 & & \\
\hline
\end{tabular}

aCompounds listed according to the elution order in HP5MS column; bretention index (RI) calculated utilizing n-alkanes $\mathrm{C} 7$ to $\mathrm{C28}$ in a capillary column (HP5-MS UI); cIdentification based on the comparison with mass spectrum from NIST 11.0 libraries; Relative area $(\%)$ : percentage of the area occupied by the compounds in the chromatogram. $n . i .=$ not identified. $t=$ traces. 


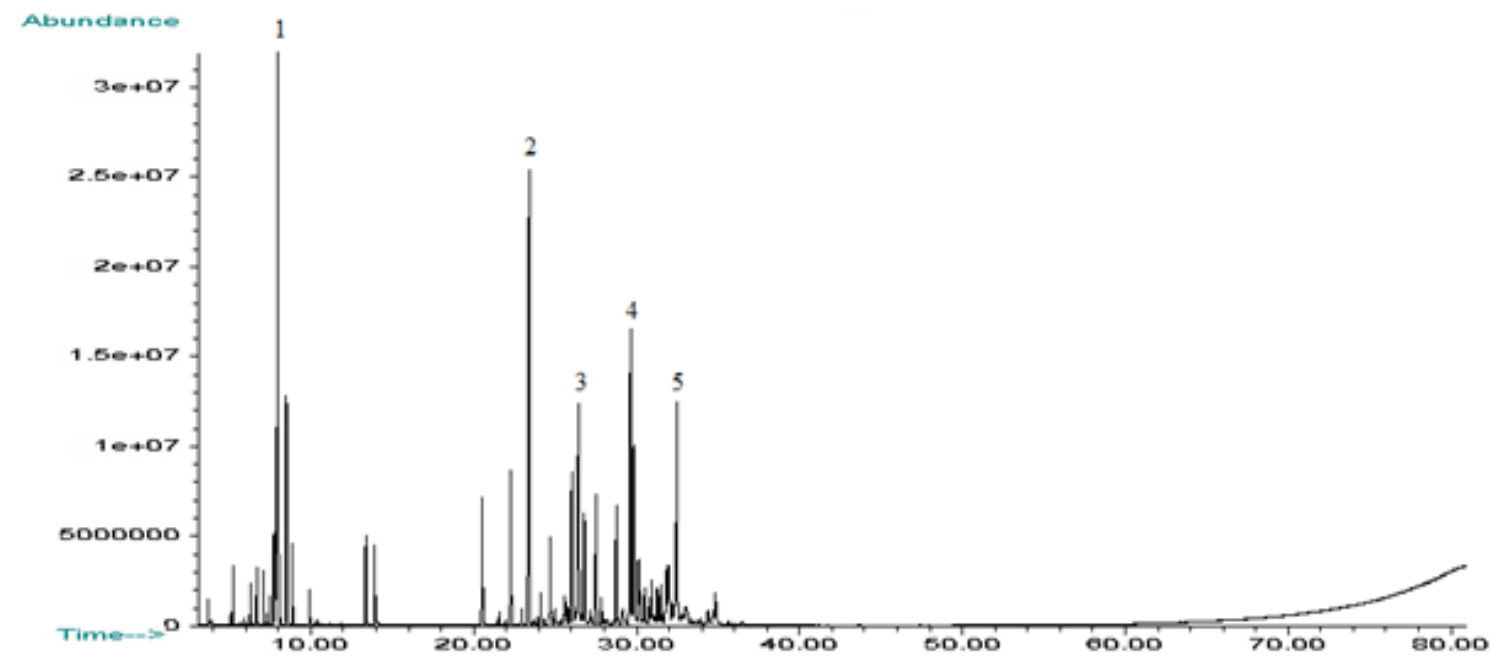

Figure No. 1

Chromatogram of Myrcianthes pungens leaf essential oil obtained by gas chromatograph coupled to mass spectrometer. (1) 1,8-cineole; (2) $\beta$-caryophyllene; (3) bicyclogermacrene; (4) spathulenol;

(5) 5-epi-neointermedeol

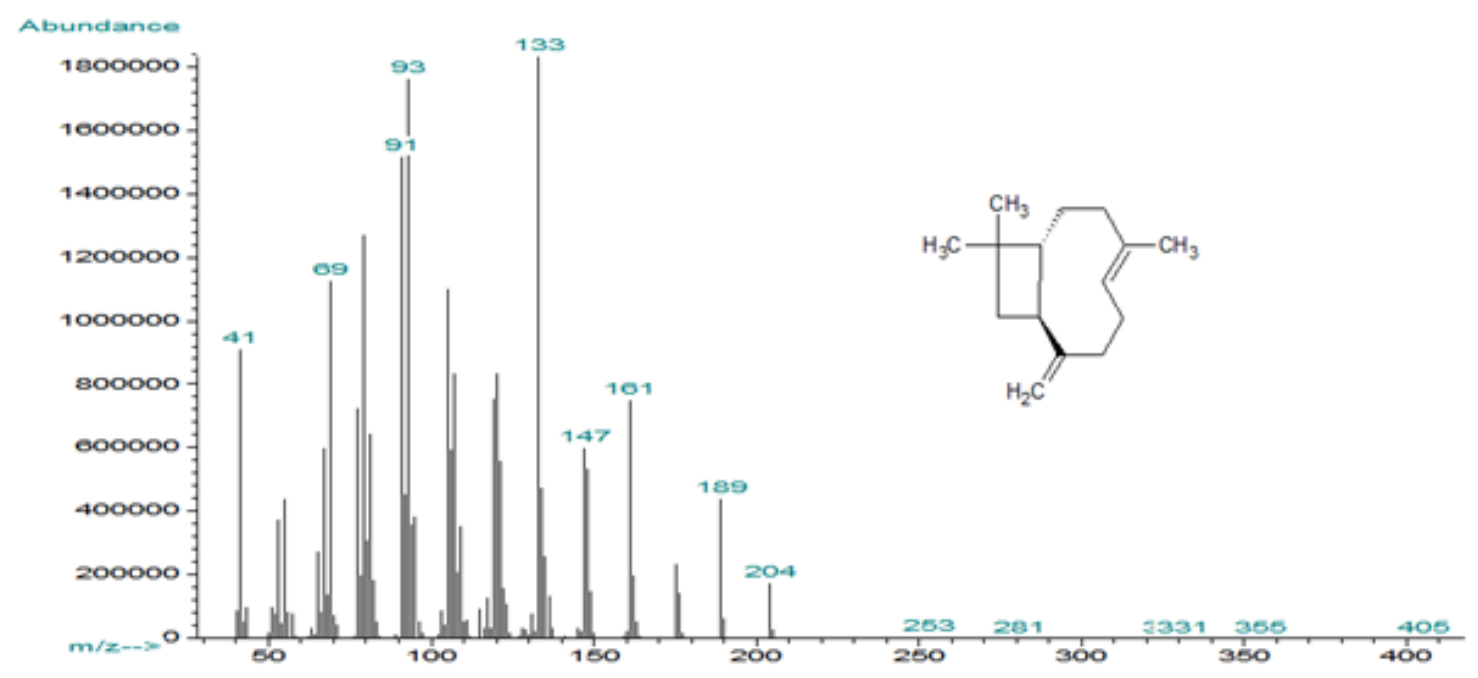

Figure No. 2

Mass spectrum of $\beta$-caryophyllene $(\mathrm{m} / \mathrm{z}=204)$ found in Myrcianthes pungens leaf essential oil obtained by gas chromatograph coupled to mass spectrometer 


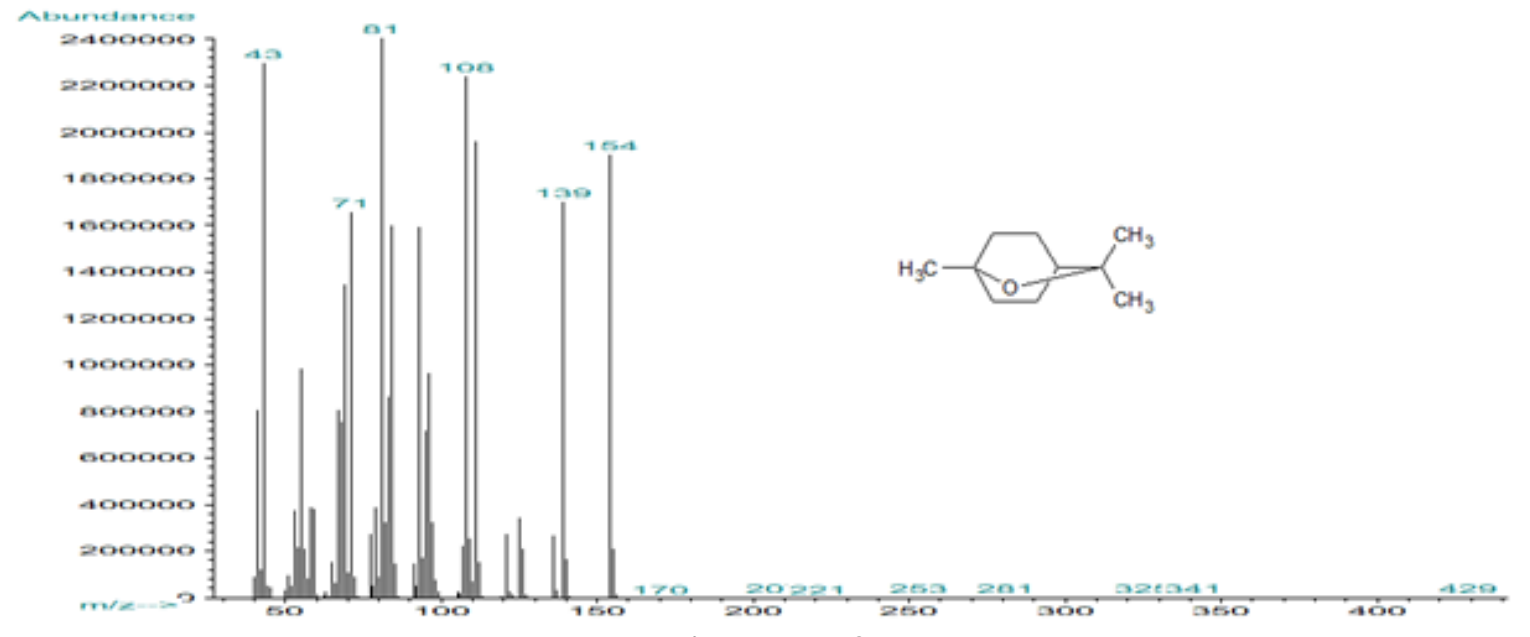

Figure No. 3

Mass spectrum of 1,8-cineole $(\mathrm{m} / \mathrm{z}=154)$ found in Myrcianthes pungens leaf essential oil obtained by gas chromatograph coupled to mass spectrometer

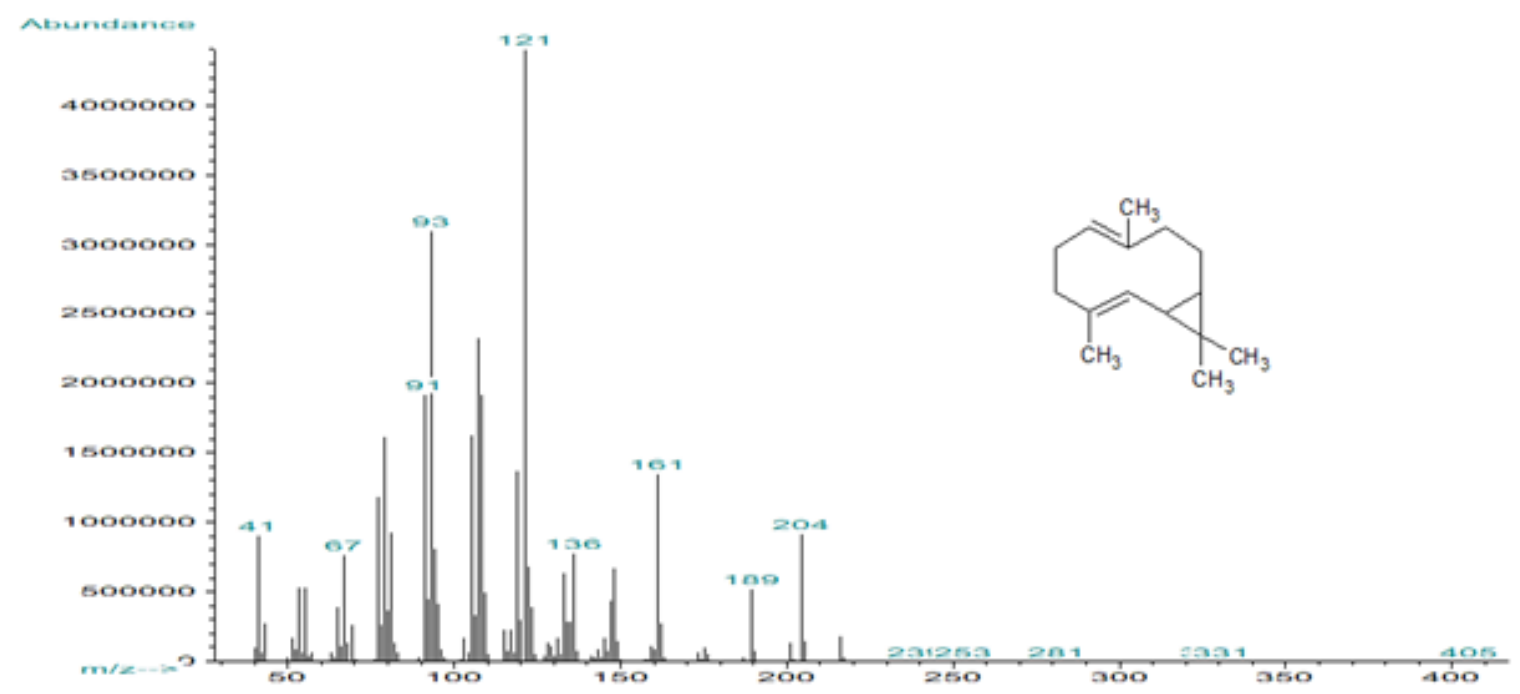

Figure No. 4

Mass spectrum of bicyclogermacrene $(\mathrm{m} / \mathrm{z}=204)$ found in Myrcianthes pungens leaf essential oil obtained by gas chromatograph coupled to mass spectrometer 


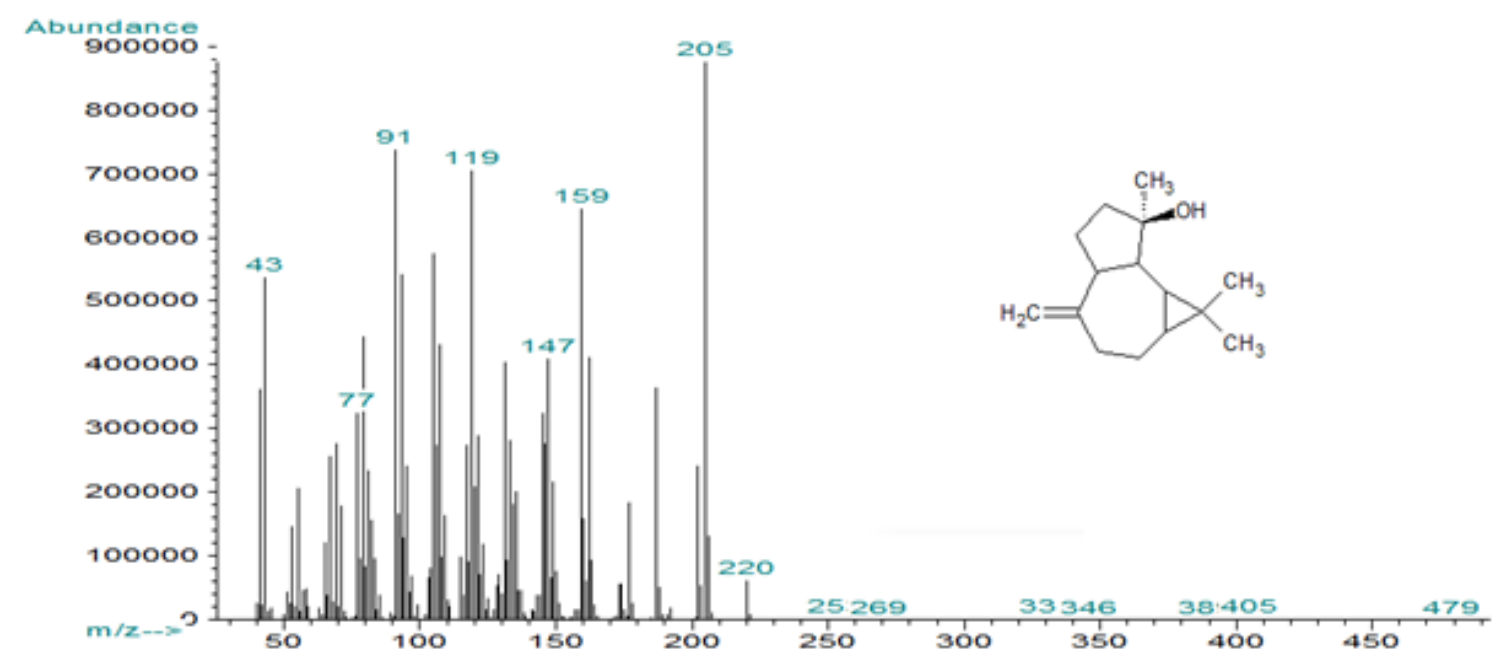

Figure No. 5

Mass spectrum of spathulenol $(\mathrm{m} / \mathrm{z}=220)$ found in Myrcianthes pungens leaf essential oil obtained by gas chromatograph coupled to mass spectrometry

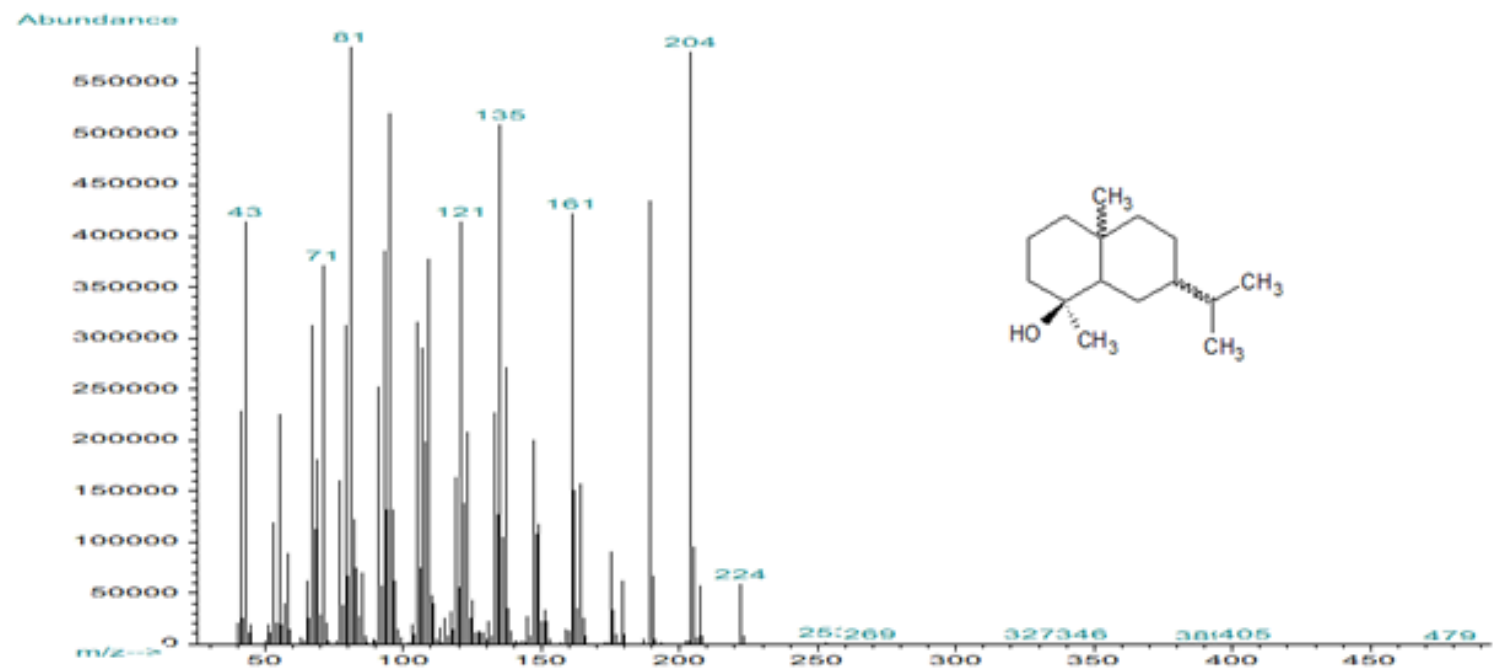

Figure No. 6

Mass spectrum of 5-epi-neointermedeol $(\mathrm{m} / \mathrm{z}=224)$ found in Myrcianthes pungens leaf essential oil obtained by gas chromatograph coupled to mass spectrometer

Essential oil antioxidant activity by DPPH• method had $\mathrm{IC}_{50}$ value of $24.47 \pm 2.03 \mathrm{mg} / \mathrm{mL}$. This value was 2447 -fold higher than quercetin, positive control (Table No. 2), indicating an essential oil with reduced antioxidant activity by $\mathrm{DPPH} \bullet$. Through FRAP method, the reducing capacity was $0.27 \mu \mathrm{M}$ $\mathrm{Fe}^{2+} / \mathrm{mg}$ of sample and comparing it to the positive control trolox it was $9.17 \mu \mathrm{M} \mathrm{Fe}^{2+} / \mathrm{mg}$ of the sample (Table No. 2), indicating an essential oil with reduced capacity to decrease $\mathrm{Fe}^{+3}$ ions. However, by BCLA method, the protecting action of the essential oil was of $57.5 \%(0.25 \mathrm{mg} / \mathrm{mL}$ essential oil) (Table No. 2). The antioxidant activity of the essential oil, a mixture of compounds, at $0.25 \mathrm{mg} / \mathrm{mL}$ was just 1.26 -fold lower than the positive control trolox $(0.2 \mathrm{mg} / \mathrm{mL})$ (Table No. 2). The absorbance reduction, which shows $\beta$-carotene oxidation by fat peroxidation chain, was lower for the positive control followed by different essential oil concentrations (Figure No. 7). This suggests that the essential oil have intermediate antioxidant activity to protect $\beta$-carotene against free radicals. 
Table No. 2

Antioxidant activity (arithmetical means \pm standard deviation; $n=3$ ) of the essential oil from Myrcianthes pungens dried leaves

Antioxidant activity $\quad * \mathrm{DPPH} \bullet \mathrm{IC}_{50}(\mathrm{mg} / \mathrm{mL}) \quad \mathrm{FRAP}\left(\mu \mathrm{M} \mathrm{Fe}^{2+} / \mathrm{mg}\right.$ of sample $) \quad$ BCLA $\beta$-carotene protection $(\%)$

\begin{tabular}{cccc}
\hline Essential oil & $24.47 \pm 2.03^{\mathrm{b}^{* *}}$ & $0.27 \pm 0.01^{\mathrm{b}}$ & $57.48 \pm 4.21^{\mathrm{b}}$ \\
\hline Quercetin & $0.01 \pm 0.01^{\mathrm{a}}$ & -- & -- \\
\hline Trolox & -- & $9.17 \pm 0.01^{\mathrm{a}}$ & $72.39 \pm 4.55^{\mathrm{a}}$
\end{tabular}

*DPPH• method (2,2-diphenyl-1-picrylhydrazyl) using quercetin as positive control $($ IC50 $=$ inhibitory concentration to reduce $50 \%$ of free radical by DPPH॰); FRAP method (ferric ion reducing antioxidant power) using trolox $(0.2 \mathrm{mg} / \mathrm{mL})$ as positive control; BCLA method ( $\beta$-carotene/linoleic acid co-oxidation system) of essential oil at $0.25 \mathrm{mg} / \mathrm{mL}$ and trolox $(0.2 \mathrm{mg} / \mathrm{mL})$ as positive control. **Different letters in the same column indicate significant differences by Tukey test $(\boldsymbol{p} \leq \mathbf{0 . 0 5})$

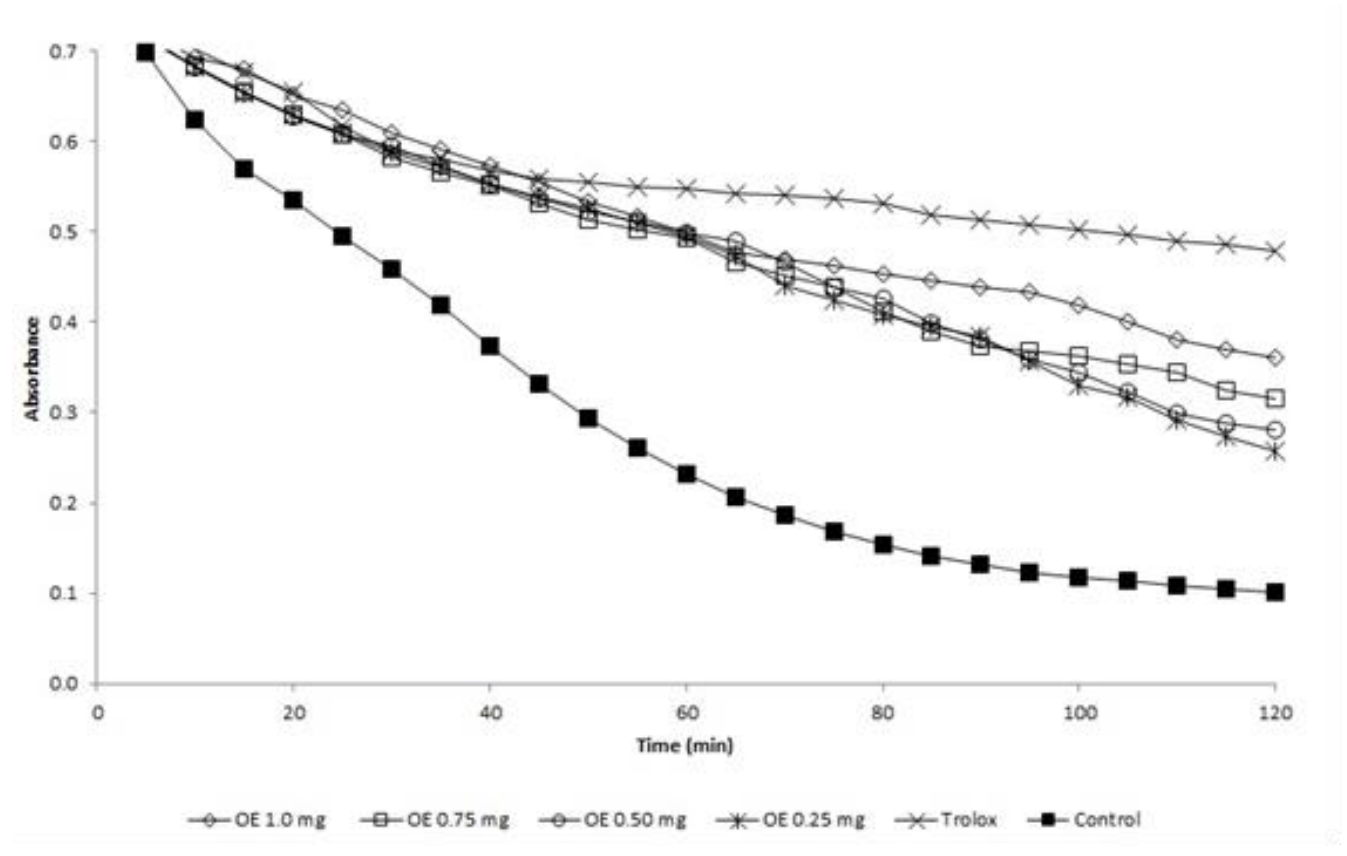

Figure No. 7

Absorbance by time through BCLA method ( $\beta$-carotene/linoleic acid co-oxidation system) of the essential oil from Myrcianthes pungens dried leaves

The antibacterial activity of the essential oil was effective and specific for $S$. aureus (78.12 $\mu \mathrm{g} / \mathrm{mL}$ ), with activity 2.56 -fold greater than the control streptomycin $(200.0 \mu \mathrm{g} / \mathrm{mL})$, which indicates essential oil high efficiency against this bacterium (Table No. 3). The essential oil did not have bacterial activity against $B$. cereus and $P$. aeruginosa, showing efficiency 801 and 33003-fold lower than the control streptomycin, respectively, and, therefore, low efficiency for the control of these bacteria (Table No. $3)$. 
Table No. 3

Minimum inhibitory concentration (MIC) of the essential oil from Myrcianthes pungens dried leaves (arithmetical mean \pm standard deviation; $n=3$ ) and streptomycin (control) against different bacteria

\begin{tabular}{lll}
\hline Bacteria & Essential oil $(\boldsymbol{\mu g} / \mathbf{m L})$ & Streptomycin $(\boldsymbol{\mu g} / \mathbf{m L})$ \\
\hline Staphylococcus aureus & $78.12 \pm<0.01^{\mathrm{aA}}$ & $200.00 \pm<0.01^{\mathrm{cB}}$ \\
\hline Bacillus cereus & $416.67 \pm 180.42^{\mathrm{bB}}$ & $0.52 \pm<0.01^{\mathrm{aA}}$ \\
\hline Pseudomonas aeruginosa & $33333.33 \pm 11547.00^{\mathrm{cB}}$ & $1.01 \pm<0.01^{\mathrm{bA}}$ \\
\hline
\end{tabular}

Different small letters in the same column and capital letters in the same row indicate significant differences by Tukey test $(p \leq 0.05)$

\section{DISCUSSION}

\section{Essential oil characteristics}

Myrcianthes pungens essential oil yield of $0.19 \%$, obtained in our study, is in accordance with the values in the literature for this plant (Table No. 4). Zygadlo et al. (1997) reported that in the province of Catamarca, Argentina, the essential oil yield from dried leaves was $0.10 \%$, and Apel et al. (2006) reported that in Rio Grande do Sul, Brazil, the essential oil yield from fresh leaves was $0.20 \%$, collected in the plant vegetative phase. According to the European Pharmacopoeia, the minimum extraction essential oil yield of $2 \mathrm{~mL} / \mathrm{kg}$ is recommended for the continuity of application development studies (Nemeth \& Bernath, 2008). The essential oil yield in our study was $1.8 \mathrm{~mL} / \mathrm{kg}$ (dry basis) indicating that it is a little lower than the recommended by European Pharmacopoeia (European Pharmacopoeia, 2013), limiting the potential use of the leaf essential oil of this plant. Notwithstanding, this is a wild plant that can still be the target of genetic breeding programs to increase the essential oil yield.

Myrtaceae family has one of the highest concentrations of foliar terpenes in the Plant Kingdom. For Padovan et al. (2014) and Zygadlo et al. (1997), 1,8-cineole is the most representative and abundant compound in the profile of foliar terpenes of this family. However, in M. pungens essential oil, the major compounds reported are $\beta$-caryophyllene $(10.1 \%)$, bicyclogermacrene $(6.9 \%)$, and 1,8-cineole (45.8\%) (Zygadlo et al., 1997; Apel et al., 2006; Marin et al., 2008). In our study, 1,8-cineole (10.1\%), $\beta$-caryophyllene (11.7\%), and bicyclogermacrene $(7.9 \%)$ were the main major compounds found. The chemical composition and the amount of essential oil compounds are modulated by the vegetative phase, chemotype, and plant extrinsic factors such as soil, temperature, rainfall among others (Figueiredo et al., 2008), which allow certain variation within the species.

$\beta$-caryophyllene has been reported as a non- steroidal anti-inflammatory agent and it has also analgesic, antipyretic, and platelet-inhibitory actions by blocking the synthesis of prostaglandins. It is found $\beta$-caryophyllene in the essential oil of Syzygium aromaticum (L.) Merr. \& Perry, Cannabis sativa L., Rosmarinus officinalis L., and Humulus lupulus L. In addition, it is reported that $99 \% \beta$ caryophyllene may be fatal if swallowed and enters airways and if at $72 \%$ may cause allergic skin reaction (PubChem, 2020). 1,8-cineole, also known as eucalyptol, has a camphor-like odor and spicy cooling taste. It has mucolytic, bronchodilating, antiinflammatory, and is used as anti-infective, mouthwashes, antitussive, and insect repellent. It is found 1,8-cineole in rhizomes of Curcuma zedoaria (Christm.) Roscoe, and leaves of Eucalyptus spp (PubChem, 2020).

Bicyclogermacrene has cytotoxic activity and may be fatal if swallowed and enters airways. It is reported as antimicrobial, acaricidal, insecticidal, antitumor, and antiprotozoal. It is found bicyclogermacrene in the essential oil of Kundmannia sicula (L.) DC. (81.2\%) and Torilis japonica (Houtt.) DC. (57.9-71.8\%) (PubChem, 2020). Spathulenol has cytotoxic activity and also antimycotic, antitumor, acaricide, antibiotic, antiseptic, contraceptive, and is used as antidepressant to treat neurodegenerative disorders of the central nervous system. It is found spathulenol in the essential oil of Campomanesia adamantium (Cambessedes) Berg, Cardiopetalum calophyllum Schltdl., Salvia sclarea L., Artemisia vulgaris L., and Artemisia dracunculus L. (PubChem, 2020). 5-epineointermedeol has been little studied, but intermedeol, which is the backbone structure of 5epi-neointermedeol, is an acaricide against several ticks such as Amblyomma cajennense Fabricius, Ixodes scapularis (current name Rhipicephalus bursa Canastrini \& Fanzago), and Amblyomma americanum Linnaeus, and repellent against arthropods such as fire ants. Intermedeol has been found in the essential oil of Cymbopogon nardus (L.) Rendle, Callicarpa

Boletín Latinoamericano y del Caribe de Plantas Medicinales y Aromáticas/156 
americana L., Callicarpa americana L., Callicarpa japonica Thunb., and Ligularia fischeri (Ledeb.)
Turcz. (PubChem, 2020).

Table No. 4

Yield, utilized plant part, hydrodistillation time and major compounds of Myrcianthes spp essential oil

\begin{tabular}{|c|c|c|c|c|}
\hline Plant & $\begin{array}{l}\text { Utilized } \\
\text { part/hydrodistillation } \\
\text { (h) }\end{array}$ & $\begin{array}{l}\text { Yield } \\
(\%)\end{array}$ & Major compounds & Reference \\
\hline M. cisplatensis & Fresh leaf /(4 h) & 0.20 & $\begin{array}{l}1,8 \text {-cineole }(29.8 \%), \text { limonene }(10.9 \%), \beta \text { - } \\
\text { caryophyllene }(10.8 \%) \text { and } \alpha \text {-pinene }(8.9 \%)\end{array}$ & $\begin{array}{l}\text { Apel et al. } \\
(2006)\end{array}$ \\
\hline M. gigantea & Fresh leaf /(4 h) & 0.10 & $\begin{array}{l}\text { spathulenol }(28.9 \%) \text {, iso-spathulenol }(9.5 \%), \alpha \text { - } \\
\text { cadinol }(7.0 \%) \text { and cariophellene oxide }(6.7 \%)\end{array}$ & $\begin{array}{l}\text { Apel et al. } \\
(2006)\end{array}$ \\
\hline M. pungens & Fresh leaf /(4 h) & 0.10 & $\begin{array}{l}\beta \text {-caryophyllene }(10.1 \%) \text {. spathulenol }(9.7 \%), \beta \text { - } \\
\text { elemene }(9.1 \%), \alpha \text {-cadinol }(8.0 \%), \\
\text { bicyclogermacrene }(6.9 \%) \text { and globulol }(6.2 \%)\end{array}$ & $\begin{array}{l}\text { Apel et al. } \\
\text { (2006) }\end{array}$ \\
\hline M. osteomeloides & Fresh leaf /(ni) & 0.60 & $\begin{array}{l}1,8 \text {-cineole }(55.7 \%), \alpha \text {-pinene }(17.9 \%) \text { and } \alpha \text { - } \\
\text { terpineol }(8.5 \%)\end{array}$ & $\begin{array}{l}\text { Arze } e t a l \text {. } \\
(2005)\end{array}$ \\
\hline M. pseudomato & Fresh leaf /(ni) & 0.10 & $\begin{array}{l}\text { 1,8-cineole }(24.4 \%), \alpha \text {-pinene }(17.1 \%), \text { linalol } \\
(11.7 \%), \text { limonene }(8.5 \%) \text { and } \gamma \text {-terpinene }(7.3 \%)\end{array}$ & $\begin{array}{l}\text { Arze et al. } \\
(2005)\end{array}$ \\
\hline M. pseudomato & Dried leaf/(ni) & 0.30 & $\begin{array}{l}\text { 1,8-cineole }(32.5 \%), \beta \text {-caryophyllene }(18.9 \%) \text {, } \\
\text { sabinene }(6.6 \%), \alpha \text {-pinene }(6.5 \%) .\end{array}$ & $\begin{array}{l}\text { Demo et al. } \\
(2002)\end{array}$ \\
\hline M. pungens & Fresh fruit/(4 h) & 0.10 & $\begin{array}{l}\beta \text {-caryophyllene }(32.7 \%) \text {, germacrene D }(14.2 \%) \\
\text { and bicyclogermacrene }(11.2 \%)\end{array}$ & $\begin{array}{l}\text { Marin et al. } \\
(2008)\end{array}$ \\
\hline M. cisplatensis & Dried leaf/(1 h) & 0.15 & $\begin{array}{l}\text { 1,8-cineole }(40.72 \%), \text { limonene }(22.14 \%), \alpha \text { - } \\
\text { terpineol }(7.71 \%)\end{array}$ & $\begin{array}{l}\text { Zygadlo et } \\
\text { al. (1997) }\end{array}$ \\
\hline M. pungens & Dried leaf/(1 h) & 0.20 & $\begin{array}{l}\text { 1,8-cineole }(45.85 \%), \text { limonene }(17.31 \%) \text { and } \alpha \text { - } \\
\text { terpineol }(8.14 \%)\end{array}$ & $\begin{array}{l}\text { Zygadlo et } \\
\text { al. (1997) }\end{array}$ \\
\hline
\end{tabular}

ni: not informed

\section{Antioxidant activity}

Most of terpenes present antioxidant properties (Škrovánková et al., 2012), however, the essential oil of $\mathrm{M}$. pungens leaves showed in our study high antioxidant activity by BCLA method and lower antioxidant activity by DPPH • and FRAP methods. Essential oils are generally poorly soluble in aqueous and methanolic solutions such as those used in the FRAP and DPPH • methods and high soluble in nonpolar media such as BCLA. Thus, chemical interactions among essential oil and solvents may explain the lower antioxidant activity of $M$. pungens essential oil by FRAP and DPPH $\bullet$ methods and the high antioxidant activity by BCLA.

$\beta$-caryophyllene hydrocarbon sesquiterpene, one of the major compounds in our study, was reported for $\mathrm{DPPH} \bullet$ method with $\mathrm{IC}_{50}$ ranging from $0.13 \mathrm{mg} / \mathrm{mL}$ (Calleja et al., 2013) to $0.28 \mathrm{mg} / \mathrm{mL}$ (Selestino Neta et al., 2017), but these authors used an isolated compound instead of crude essential oil. According to Selestino Neta et al. (2017) essential oils with great concentration of monoterpenes with aromatic rings attached to hydroxyl groups have high antioxidant activity but conversely essential oils with great concentration of sesquiterpene hydrocarbons, such as in our study, have low antioxidant activity to scavenge free radical as DPPH $\bullet$.

Wannes et al. (2010) reported that stem essential oil of Myrtus communis var. italica (Myrtaceae), which had as major compound 1,8- 
cineole $(32.8 \%)$, had a reduced capacity to chelate iron ions. Lee \& Shibamoto (2001) reported that 1,8cineole had small antioxidant activity in polar condition and high activity in organic and lipid systems. These reports indicate that this compound has reduced antioxidant activity in polar systems and high antioxidant activity in lipid systems, as found in our study.

Jayasena \& Jo (2013) reported that the use of natural products against the lipid oxidation in food products. In addition, Falowo et al. (2014) carried out extensive literature revision on the use of extracts of medicinal plants as phytoremedy against lipidprotein oxidation and synergistic antimicrobial activity of these natural antioxidants were reported against oxidative deterioration with addition from 0.0005 to $2.0 \%$ in meat and meat products, enhancing their functional properties and meat conservation. Therefore, it suggests that $M$. pungens essential oil obtained in our study has potential application to inhibit the oxidation in food susceptible to lipid oxidation at $1.0 \mathrm{mg} / \mathrm{mL}$, equivalent to $0.1 \%$ in food.

\section{Antibacterial activity}

Non-polar compounds such as cyclic hydrocarbons can penetrate the bacterial lipid bilayer by diffusion transfer. These compounds accumulate in the cell membrane, causing their integrity loss (Sikkema et al., 1995) and/or increasing their permeability, favoring ion overflow, ATP intracellular depletion, and death (Burt, 2004). Terpenes are molecules that mimic effects of other toxins and act as cellular membrane solvents (Gershenzon \& Dudareva, 2007). In our study, the major compound class was hydrocarbon sesquiterpenes and oxygenated sesquiterpenes that act on the bacterial lipid bilayer and may be the main mechanism of action of the antibacterial activity of M. pungens essential oil.

Hendry et al. (2009) reported antibacterial activity of 1,8-cineole against $S$. aureus and $P$. aeruginosa, but at a 64-fold higher concentration, indicating that the antimicrobial activity of $M$. pungens oil against $S$. aureus was already expected. $S$. aureus is a Gram-positive bacterium responsible for several infectious processes with different degrees of virulence and resistance to antibiotics (Plata et al., 2009). M. pungens essential oil may be a new alternative to control this microorganism.

However, in our study, M. pungens essential oil was little effective against $P$. aeruginosa, a Gramnegative bacterium capable of adapting to several conditions of $\mathrm{pH}$ and temperature, and is related to serious infections in patients with a weak immune system. Gram-negative bacteria have a hydrophobic polysaccharide layer for non-polar compounds (Sikkema et al., 1995), which can explain the lower effectiveness of $M$. pungens essential oil against $P$. aeruginosa. Also, the cellular membrane of $\mathrm{P}$. aeruginosa has an efflux pump such as MexABOprM, and porins that increased the microorganism tolerance against terpene compounds such as 1,8cineole (Papadopoulos et al., 2008).

$M$. pungens essential oil was not effective against $B$. cereus, a Gram-positive and facultative aerobic bacterium that can produce endospores, which make it more resistant to antibiotics and/or form biofilms that physically protect the microorganisms and prevent antibacterial activity (Valero et al., 2006). It has been shown that B. cereus has one or more plasmids, which contributes to its virulence and pathogenicity (Helgason et al., 2000). Although it is a Gram-positive bacterium, such as $S$. aureus. Although it is a Gram-positive bacterium, such as $S$. aureus, used strain of $B$. cereus showed resistance to the crude essential oil of M. pungens. The 1,8-cineole is reported as effective against $\mathrm{S}$. aureus with MIC values ranging from 8 to $64 \mathrm{mg} / \mathrm{mL}$ (Mulyaningsih et al., 2010). $\beta$-caryophyllene is also reported as effective against $S$. aureus with MIC value of $1 \mathrm{mg} / \mathrm{mL}$, and other Gram-positive and Gram-negative bacteria (Selestino Neta, 2017). In our study, the crude essential oil, containing 1,8-cineole and $\beta$-caryophyllene as major compounds, was effective against $\mathrm{S}$. aureus with MIC value ranging from 102 to 819 -fold lower than the isolated 1,8cineole (Mulyaningsih et al., 2010). Further tests would clarify a possible synergistic effect between these essential oil compounds.

\section{CONCLUSION}

The yield of essential oil from $M$. pungens dried leaves is $0.2 \%$ with $0.98 \mathrm{~g} / \mathrm{mL}$ density, and 1.4980 refraction index. Essential oil major compounds are $\beta$-caryophyllene (11.7\%), 1,8-cineole (10.1\%), bicyclogermacrene (7.9\%), spathulenol $(7.8 \%)$, and 5-epi-neointermedeol (6.0\%). From the total identified compounds, $42.6 \%$ are hydrocarbon sesquiterpenes and $30.7 \%$ are oxygenated sesquiterpenes. The essential oil has high antioxidant activity by BCLA method with protective action of $\beta$ carotene of $57.5 \%$ at $0.25 \mathrm{mg} / \mathrm{mL}$ but it has low antioxidant activity by $\mathrm{DPPH} \cdot$ and FRAP methods. The crude essential oil has antibacterial activity against $S$. aureus but it is not effective against $B$. cereus and $P$. aeruginosa, indicating selective antibacterial activity. 


\section{ACKNOWLEDGEMENTS}

The authors thank Universidade Paranaense, Coordenação de Aperfeiçoamento de Pessoal de

Nível Superior - Brazil (CAPES) -finance code 001-,
Fundação Araucária and Conselho Nacional de Desenvolvimento Científico e Tecnológico (CNPq) for the financial support.

\section{REFERENCES}

Adams RP. 2012. Identification of essential oil components by gas chromatography/mass spectrometry. 4th edn. Allured Publishing Corporation, Illinois, USA.

Andrade JMM, Aboy AL, Apel MA, Raseira MC, Pereira JF, Henriques AT. 2011. Phenolic composition in different genotypes of guabiju fruits (Myrcianthes pungens) and their potential as antioxidant and antichemotactic agents. J Food Sci 76: 1181 - 1187. https://doi.org/10.1111/j.1750-3841.2011.02375.x

Anyanwu MU, Okoye RC. 2017. Antimicrobial activity of Nigerian medicinal plants. J Intercult Ethnopharmacol 6: 240 - 259. https://doi.org/10.5455/jice.20170106073231

Apel MA, Sobral M, Henriques AT. 2006. Chemical composition of the volatile oils of native Myrcianthes species from South Brazil. Braz J Pharmacogn 16: 402 - 407.

Arze JBL, Jean FI, Gagnon H, Collin G, Garneau FX, Pichette A. 2005. Essential oils from Bolivia. VII. Myrtaceae: Myrcianthes osteomeloides (Rusby) McVaugh and Myrcianthes pseudomato (Legrand) McVaugh. J Essent Oil Res 17: 64 - 65. https://doi.org/10.1080/10412905.2005.9698832

Burt S. 2004. Essential oils: their antibacterial properties and potential applications in foods - a review. Int J Food Microbiol 94: 223 - 253. https://doi.org/10.1016/j.ijfoodmicro.2004.03.022

Calleja MA, Vieites JM, Montero-Meterdez T, Torres MI, Faus MJ, Gil A, Suárez A. 2013. The antioxidant effect of $\beta$-caryophyllene protects rat liver from carbon tetrachloride-induced fibrosis by inhibiting hepatic stellate cell activation. Br J Nutr 109: 394 - 401. https://doi.org/10.1017/s0007114512001298

CLSI. 2006. Performance standards for antimicrobial susceptibility testing: CLSI approved standard M100S1, Clinical and Laboratory Standards Institute, Wayne, USA.

Demo MS, Oliva MM, Zunino MP, Lopez ML, Zygadlo JA. 2002. Aromatic plants from Yungas. Part IV: composition and antimicrobial activity of Myrcianthes pseudomato essential oil. Pharm Biol 40: 481 - 484. https://doi.org/10.1076/phbi.40.7.481.14689

European Pharmacopoeia. 2013. 8th edn. Council of Europe, Strasbourg, France.

Falowo AB, Fayemi PO and Muvhenje V. 2014. Natural antioxidants against lipid-protein oxidative deterioration in meat and meat products: a review. Food Res Int 64: 171 - 181. https://doi.org/10.1016/j.foodres.2014.06.022

Farmacopeia Brasileira. 2010. 5th edn. Agência Nacional de Vigilância Sanitária, Brasília, Brasil.

Figueiredo AC, Barroso JG, Pedro LG, Scheffer JJ. 2008. Factors affecting secondary metabolite production in plants: volatile components and essential oils. Flavour Fragr J 23: 213 - 226.

https://doi.org/10.1002/ffj.1875

Gershenzon J, Dudareva N. 2007. The function of terpene natural products in the natural world. Nat Chem Biol 3: 408 - 414. https://doi.org/10.1038/nchembio.2007.5

Hassler M. 2019. World plants: synonymic checklists of the vascular plants of the world (version Nov 2018). In: Species 2000 \& ITIS Catalogue of Life, 26th February 2019 (Roskov Y, Ower G, Orrell T, Nicolson D, Bailly N, Kirk PM, Bourgoin T, DeWalt RE, Decock W, Nieukerken E, Zarucchi J, Penev L, eds.). Digital resource at www.catalogueoflife.org/col. Species 2000: Naturalis, Leiden, The Netherlands.

Helgason E, Okstad OA, Caugant DA, Johansen HA, Fouet A, Mock M, Hegna I, Kolstø AB. 2000. Bacillus anthracis, Bacillus cereus, and Bacillus thuringiensis - one species on the basis of genetic evidence. Appl Environ Microbiol 66: 2627 - 2630. https://doi.org/10.1128/aem.66.6.2627-2630.2000

Hendry ER, Worthington T, Conway BR, Lambert PA. 2009. Antimicrobial efficacy of eucalyptus oil and 1,8cineole alone and in combination with chlorhexidine digluconate against microorganisms grown in planktonic and biofilm cultures. J Antimicrob Chemother 64: 1219 - 1225.

https://doi.org/10.1093/jac/dkp362

Jayasena DD, Jo C. 2013. Essential oils as potential antimicrobial agents in meat and meat products: a review. Trends Food Sci Technol 34: 96 - 108. https://doi.org/10.1016/j.tifs.2013.09.002

Lee KG, Shibamoto T. 2001. Antioxidant activities of volatile components isolated from Eucalyptus species. J Sci Food Agric 81: 1573 - 1579. https://doi.org/10.1002/jsfa.980 
Marin R, Apel MA, Limberger RP, Raseira MCB, Pereira JFM, Zuanazzi JÂS, Henriques AT. 2008. Volatile components and antioxidant activity from some Myrtaceous fruits cultivated in Southern Brazil. Lat Am J Pharm 27: 172 - 177.

Mulyaningsih S, Sporer F, Zimmermann S, Reichling J. 2010. Synergistic properties of the terpenoids aromadendrene and 1,8-cineole from the essential oil of Eucalyptus globulus against antibiotic-susceptible and antibiotic-resistant pathogens. Phytomedicine 17: 1061 - 1066.

https://doi.org/10.1016/j.phymed.2010.06.018

Nemeth E, Bernath J. 2008. Biological activities of yarrow species (Achillea spp.). Curr Pharm Des 14: 3151 3167. https://doi.org/10.2174/138161208786404281

Newman DJ, Cragg GM. 2012. Natural products as sources of new drugs over the 30 years from 1981 to 2010. J Nat Prod 75: 311 - 335. https://doi.org/10.1021/np200906s

Nora CD, Danelli D, Souza LF, Rios ADO Jong EV, Flôres SH. 2014 Protective effect of guabiju (Myrcianthes pungens (O. Berg) D. Legrand) and red guava (Psidium cattleyanum Sabine) against cisplatin-induced hypercholesterolemia in rats. Braz J Pharm Sci 50: 483 - 491.

https://doi.org/10.1590/s1984-82502014000300006

Padovan A, Keszei A, Külheim C, Foley WJ. 2014. The evolution of foliar terpene diversity in Myrtaceae. Phytochem Rev 13: 695 - 716. https://doi.org/10.1007/s11101-013-9331-3

Papadopoulos CJ, Carson CF, Chang BJ, Riley TV. 2008. Role of the MexAB-OprM efflux pump of Pseudomonas aeruginosa in tolerance to tea tree (Melaleuca alternifolia) oil and its monoterpene components terpinen-4ol, 1,8-cineole, and $\alpha$-terpineol. J Appl Environ Microbiol 74: 1932 - 1935.

https://doi.org/10.1128/aem.02334-07

Plata K, Rosato AE, Wegrzyn G. 2009. Staphylococcus aureus as an infectious agent: overview of biochemistry and molecular genetics of its pathogenicity. Acta Biochim Pol 56: 597 - 612. https://doi.org/10.18388/abp.2009_2491

PubChem. 2020. Database of chemical molecules, and their activities against biological assay, National Center for Biotechnology Information (NCBI), National Library of Medicine, NIH - National Institutes of Health, U.S. Department of Health \& Human Services. https://pubchem.ncbi.nlm.nih.gov

Rufino MDSM, Alves RE, Brito ES, Morais SM, Sampaio CG, Pérez-Jiménez J, Saura-Calixto FD. 2006. Scientific methodology: determination of total antioxidant activity in fruits by the iron reduction method (FRAP). Comunicado Técnico 125. Embrapa Agroindústria Tropical, Fortaleza, Brasil.

http://www.infoteca.cnptia.embrapa.br/infoteca/handle/doc/664098

Rufino MDSM, Alves RE, Brito ES, Morais SM, Sampaio CG, Pérez-Jiménez J, Saura-Calixto FD. 2007. Scientific methodology: determination of total antioxidant activity in fruits by free radical capture DPPH. Comunicado Técnico 127. Embrapa Agroindústria Tropical, Fortaleza, Brasil. https://www.infoteca.cnptia.embrapa.br/infoteca/bitstream/doc/426953/1/Cot127.pdf

Selestino Neta MC, Vittorazzi C, Guimarães AC, Martins JDL, Fronza M, Endringer DC, Scherer R. 2017. Effects of $\beta$-caryophyllene and Murraya paniculata essential oil in the murine hepatoma cells and in the bacteria and fungi 24-h time-kill curve studies. Pharm Biol 55: 190 - 197.

https://doi.org/10.1080/13880209.2016.1254251

Sikkema J, Bont JA, Poolman B. 1995. Mechanisms of membrane toxicity of hydrocarbons. Microbiol Mol Biol Rev 59: 201 - 222. https://doi.org/10.1128/mmbr.59.2.201-222.1995

Škrovánková S, Misurcová L, Machu L. 2012. Antioxidant activity and protecting health effects of common medicinal plants. Adv Food Nutr Res 67: 75 - 139. https://doi.org/10.1016/b978-0-12-394598-3.00003-4

Suh HJ, Chung MS, Cho YH, Kim JW, Kim DH, Han KW, Kim CJ. 2005. Estimated daily intakes of butylated hydroxyanisole (BHA), butylated hydroxytoluene (BHT) and tert-butyl hydroquinone (TBHQ) antioxidants in Korea. Food Addit Contam 22: 1176 - 1188. https://doi.org/10.1080/02652030500195288

Valero M, Sarrías JA, Alvarez D, Salmerón MC. 2006. Modeling the influence of electron beam irradiation on the heat resistance of Bacillus cereus spores. Food Microbiol 23: 367 - 371.

https://doi.org/10.1016/j.fm.2005.05.006

Velioglu YS, Mazza G, Gao L, Oomah BD. 1998. Antioxidant activity and total phenolics in selected fruits, vegetables, and grain products. J Agric Food Chem 46: 4113 - 4117.

https://doi.org/10.1021/jf9801973

Wannes WA, Mhamdi B, Sriti J, Jemia MB, Ouchikh O, Hamdaoui G, Kchouk EM, Marzouk, B. 2010. 
Antioxidant activities of the essential oils and methanol extracts from myrtle (Myrtus communis var. italica) leaf, stem and flower. Food Chem Toxicol 48: 1362 - 1370. https://doi.org/10.1016/j.fct.2010.03.002

Yehye WA, Rahman NA, Ariffin A, Hamid SBA, Alhadi AA, Kadir FA, Yaeghoobi M. 2015. Understanding the chemistry behind the antioxidant activities of butylated hydroxytoluene (BHT): a review. Eur J Med Chem 101: 295 - 312. https://doi.org/10.1016/j.ejmech.2015.06.026

Zygadlo JA, Rotman AD, Perez Alonso MJ, Negueruela AV. 1997. Leaf oils of two Myrcianthes species from Argentina: M. pungens (Berg.) Legrand and M. cisplatensis (Camb.) Berg. J Essent Oil Res 9: 237 - 239. https://doi.org/10.1080/10412905.1997.9699470 